\title{
Evaluation of Aesthetic Aspects in the Landscape Hardscape Elements of the Ancol Art Market Area in Jakarta Indonesia
}

\author{
Mirekel Vania Adhitya ${ }^{1}$, Rustam Hakim Manan ${ }^{2}$, Qurrotu'Aini Besila ${ }^{3}$ \\ 1,2,3. Department of Landscape Architecture, Faculty of Landscape Architecture and Environmental Technology. Universitas \\ Trisakti. Jl. Kyai Tapa No.1. Grogol Jakarta 11440 Indonesia
}

\begin{abstract}
Ancol Art Market is a center for arts and crafts that is an inspiration and insight for connoisseurs, art collectors, and entrepreneurs. The Art Center of Taman Impian Jaya Ancol's Art Market was established on an area of 5.25 hectares. Ancol Art Market has 210 stalls that are used by artists and artisans as ceramics, painting and sculpture workshops, there is also an art academy education. At present the art market is rarely visited and is in demand by visitors, thus affecting the artists who are there. One of influencing factors is the lack of maintenance in the art market, which causes a gloomy and unkept impression, the arrangement of outdoor space with too many pavement elements that is 30 percents and the increasing number of art galleries in Jakarta which makes visitors prefer to visit the art gallery rather than the Ancol Art Market. The purpose of this research is studying the various aspects of the aesthetics of landscape element that exist in the Ancol Art Market, analyze the aesthetic of the relationship with the existing landscape element and perform proposing to support the aesthetic aspect in Ancol Art Market. The method used is descriptive analytical, using data collection techniques such as observation and literature study. The results of the analysis are expected to be considered in the landscape design development of the Ancol Art Market.
\end{abstract}

Keyword: Ancol Art Market, aesthetic aspects, application in landscape element

\section{INTRODUCTION}

Taman Impian Jaya Ancol Art Market is a cultural arts center that houses multi-disciplinary arts. Since its founding in 1977, Ancol Art Market has become a rich historical platform that is important for the development of art and culture in Jakarta and Indonesia (https://www.ancol.com/ id/destination/pasar-seni). Located in Jakarta with an area of 5.25 hectares, it is a center for arts and crafts which is an inspiration for visitors, art collectors and entrepreneurs. There are 210 stalls used by painters and craftsmen as ceramics, art sculpture, traditional dance workshops, and there is an Art Academy education (https://www.ancol.com/en/destination/pasar-seni). Very famous in the 1980s, many tourists came to see various arts events such as; jazz music concerts, theater, shadow puppets, jaipongan, and others (Saidi, 2008 in Nugroho, 2010: 9). Since 1995 there has been a phenomenon of a decrease in the number of visitors due to changes in the physical and landscape aesthetic conditions of the Ancol Art Market. Based on this phenomenon, this paper will discuss the evaluation of the landscape aesthetic aspects of the hardscape element in the Ancol Art Market. In a site there are various kinds of elements, one of which is a landscape element. Landscape elements consisting of landform, building, site structure, pavement, vegetation, water (Booth, 1983). Landscape elements can also be divided into softscape and hardscape. Hardscape is a feature of an area that has been built out of hard materials such as concrete, rather than natural features such as trees and grass. (www.dictionary.cambridge.org). So, hardscape is a feature built by hard materials. The results of the study are expected to be taken into consideration for the development of the Ancol Art Market. The purpose of this study is to evaluate the hardscape of the Ancol Art Market aesthetically with a visual approach and to provide a hardscape proposal that can increase the landscape aesthetic value of the Ancol Art Market.

\section{METHODS}

This research uses descriptive analytical method. The data was calculated qualitatively using the Formal Aesthetic method in tabular form to calculate the aesthetic quality. The formal aesthetic method is the visual aesthetic value inherent in the formal nature of the landscape. This property is defined as its basic shape, line, color, texture and relation. Relationships between elements are then examined to classify each area, in terms of unity of variety, integrity, or other formal characteristics (Daniel and Vining, 1983 in Krisantia, 2012: 43). Aesthetic assessment of Hardscape elements (building, site structure, pavement) as part of aesthetic elements (shape, texture, color) (Alexander, 1976: 13-41) using aesthetic qualities (unity, symmetry, balance, harmony, contrast) (Alexander, 1976: 12) as an indicator of this study. This Formal Aesthetic Method is an assessment conducted by researchers. Aesthetic quality assessment is carried out on the basis of science and theories about aesthetics that are obtained and used in theoretical studies. There are several stages carried out in this study, namely; data collection stage, determination of research observation points, analysis and synthesis, research results in the form of a proposed hardscape development at Ancol Art Market. 


\subsection{Variables, Sub-variables and Indicators}

Table 1. Variables, Sub-variables and Indicators

\begin{tabular}{|c|c|c|}
\hline Variabel & Sub variabel & Indicators \\
\hline Building & Form & Unity \\
\hline Site Structure & Texture & Symmetry \\
\hline Pavement & Colour & Balance \\
\hline & & Harmony \\
\hline & & Contrast \\
\hline
\end{tabular}

Source: Auhors

\subsection{Data collection technique}

Data collected includes art market theory, aesthetic theory, landscape element theory, Ancol Art Market master plan, current site conditions data. Theories that support research are obtained from the results of literature studies, master plan drawings obtained from PT. Pembangunan Jaya Ancol, while the current site conditions were obtained from field observations. Secondary data obtained through literature books, and journals that have topics and footprints in accordance with the research conducted. Field observations were carried out to obtain information directly about the current site conditions, as well as to find out what hardscape elements are found in the Ancol Art Market. The master plan is used as primary data to determine the point of observation to be carried out on the site.

\subsection{Determination of observation points}

This stage to determine at which point the observations will be made. Observations made on the Ancol Art Market observations were made at 5 observation points. The observation points were carried out at four main entrances located at the Ancol Art Market; East, West, North and South Entrance as well as the main plaza of Ancol Art Market. These points are taken based on the importance of an entrance as the entry point for visitors and the main plaza in Ancol Art Market as the main activity space on the site and as the main axis point on the site. At each observation point three viewpoints were taken to take photographs to be assessed through the images. The angle of shooting at the point of observation is taken with each angle of $40^{\circ}$. According to Julius Panero and Martin Jelnik (1979) in his book entitled Human Dimension and Interior Space, the maximum human viewpoint in outdoor space is $60^{\circ}$, with an effective perspective of $40^{\circ}$.

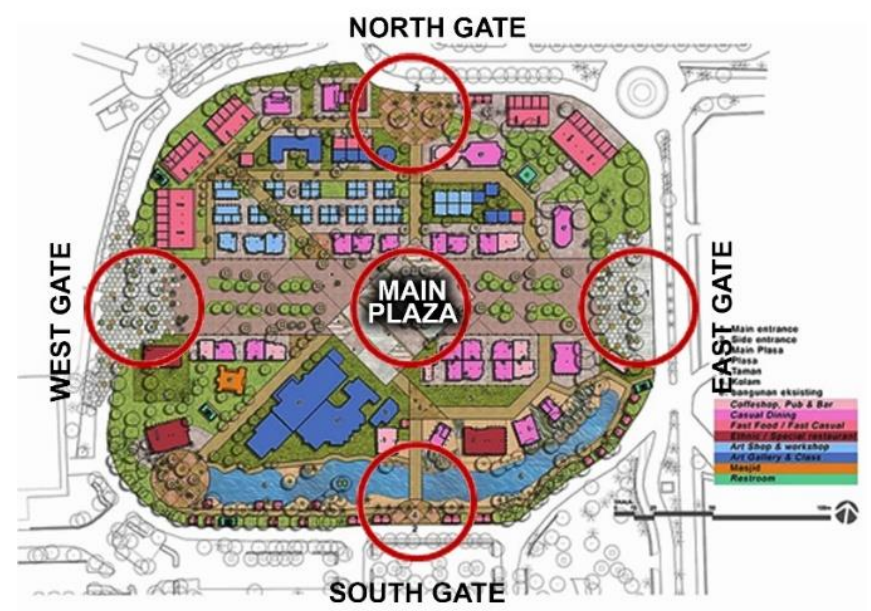

Figure 1. Observation Points at Ancol Art Market Source: PT. Pembangunan Jaya Ancol

\subsection{Analysis Techniques}

The data analysis technique used in this study is to calculate the aesthetic quality found in the Ancol Art Market. Data analysis was performed by conducting aesthetic quality assessments using a previously made Formal Aesthetic assessment table. At each observation point, 3 consecutive viewing angles were taken with a taking angle of $60^{\circ}$, so that in one observation point the total viewpoints obtained were $180^{\circ}$. In the assessment table there are items in the form of; variables, sub variables, indicators, ratings and view points. This variable is what hardscape element will be assessed at each view point, so that the elements that are reviewed at each observation point are the building, site structure and pavement. For each variable, there are sub variables which are aesthetic elements that will be seen in each existing hardscape element. Sub variables that are seen are the shape, texture and color that exist in the hardscape elements of the building, site structure and pavement in each corner of the observation at the five points of observation that have been determined. Each sub-variable is assessed based on what aesthetic quality indicators are found in each view point. These indicators are unity, symmetry, balance, harmony, and contrast. 
The method of assessment using this Formal Aesthetic table is that at each point of view taken, it is seen whether the aesthetic elements (shapes, textures and colors) on the hardscape elements (buildings, site structure and pavement) have aesthetic qualities (unity, symmetry, balance, harmony, and contrast). The aesthetic quality that is an indicator, is seen based on the relationship of all elements of the hardscape found in each angle of observation taken. After each point of view at all points of observation is assessed in the Formal Aesthetic table, the number of points obtained at the view point is added up and the total number of points at each point of view will be obtained. The total number of points at each point of observation will reflect the aesthetic value found at the point of view at that point. The number of each point in total in the point of view will be compared so that the results of comparative analysis of aesthetic quality points are obtained. Comparison of the results of the number of points is then described, the aesthetic quality of any hardscape element that affects the difference in the number of points at the point of observation, so that it looks short and excess of the aesthetic value at each point of observation. The strengths and weaknesses of hardscape aesthetics based on the results of an aesthetic quality assessment will result in proposals that will be used in the landscape development of the Ancol Art Market.

Table 2. Aesthetic Quality Assessment

\begin{tabular}{|c|c|c|c|c|c|c|}
\hline \multirow[b]{2}{*}{ Variable } & \multirow{2}{*}{$\begin{array}{c}\text { Sub } \\
\text { variable }\end{array}$} & \multirow[b]{2}{*}{ Indicators } & \multirow[b]{2}{*}{ Rating } & \multicolumn{3}{|c|}{ View Point } \\
\hline & & & & View 1 & $\begin{array}{c}\text { View } \\
2 \\
\end{array}$ & View 3 \\
\hline \multirow{15}{*}{ Building } & \multirow[t]{5}{*}{ Form } & Unity & 1 & & & \\
\hline & & Symmetry & 1 & & & \\
\hline & & Balance & 1 & & & \\
\hline & & Harmony & 1 & & & \\
\hline & & Contrast & 1 & & & \\
\hline & \multirow[t]{5}{*}{ Texture } & Unity & 1 & & & \\
\hline & & Symmetry & 1 & & & \\
\hline & & Balance & 1 & & & \\
\hline & & Harmony & 1 & & & \\
\hline & & Contrast & 1 & & & \\
\hline & \multirow[t]{5}{*}{ Colour } & Unity & 1 & & & \\
\hline & & Symmetry & 1 & & & \\
\hline & & Balance & 1 & & & \\
\hline & & Harmony & 1 & & & \\
\hline & & Contrast & 1 & & & \\
\hline \multirow{15}{*}{ Site Structure } & \multirow[t]{5}{*}{ Form } & Unity & 1 & & & \\
\hline & & Symmetry & 1 & & & \\
\hline & & Balance & 1 & & & \\
\hline & & Harmony & 1 & & & \\
\hline & & Contrast & 1 & & & \\
\hline & \multirow[t]{5}{*}{ Texture } & Unity & 1 & & & \\
\hline & & Symmetry & 1 & & & \\
\hline & & Balance & 1 & & & \\
\hline & & Harmony & 1 & & & \\
\hline & & Contrast & 1 & & & \\
\hline & \multirow[t]{5}{*}{ Colour } & Unity & 1 & & & \\
\hline & & Symmetry & 1 & & & \\
\hline & & Balance & 1 & & & \\
\hline & & Harmony & 1 & & & \\
\hline & & Contrast & 1 & & & \\
\hline \multirow{16}{*}{ Pavement } & \multirow[t]{5}{*}{ Form } & Unity & 1 & & & \\
\hline & & Symmetry & 1 & & & \\
\hline & & Balance & 1 & & & \\
\hline & & Harmony & 1 & & & \\
\hline & & Contrast & 1 & & & \\
\hline & \multirow[t]{5}{*}{ Texture } & Unity & 1 & & & \\
\hline & & Symmetry & 1 & & & \\
\hline & & Balance & 1 & & & \\
\hline & & Harmony & 1 & & & \\
\hline & & Contrast & 1 & & & \\
\hline & \multirow[t]{5}{*}{ Colour } & Unity & 1 & & & \\
\hline & & Symmetry & 1 & & & \\
\hline & & Balance & 1 & & & \\
\hline & & Harmony & 1 & & & \\
\hline & & Contrast & 1 & & & \\
\hline & \multicolumn{3}{|c|}{ Amount } & & & \\
\hline
\end{tabular}

Source: Krisantia, Visual Landscape Evaluation of Tourism Area in West Java, Indonesia. 2012: 43 


\section{DISCUSSION AND RESULTS}

\subsection{General Condition of the Location}

Location of the study was conducted at Taman Impian Jaya Ancol Art Market, North Jakarta. Initially the Ancol area was a swamp, which was then planned by Indonesian President Ir. Soekarno, to be developed into a tourist destination. In 1966 the Ancol area was built by reclaiming the area (Corporate Ancol, 2018, https://korporat.ancol.com/id/page/sejarah). Taman Impian Jaya Ancol is a reclamation area with a recreational function. One tourist destination is the Ancol Art Market with an area of 5.25 hectares.

\subsection{Observation Results}

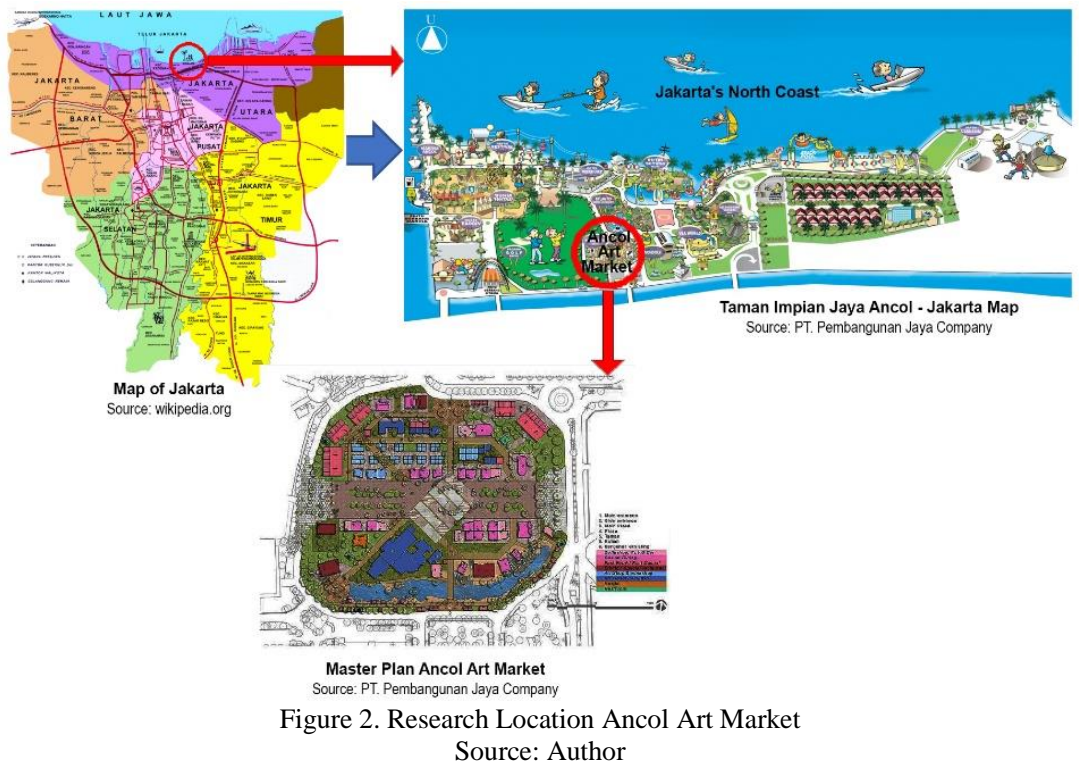

\subsubsection{Gate/ Entrance}

There are 4 entrances in the Ancol Art Market area which borders the Ancol Eco Park area. Each entrance has a different characteristic / theme. At the north entrance, there is a sculpture in the form of Borobudur with bright colors matching the colorful lanterns. The east entrance has a gate with a Betawi theme and is decorated with two ondel-ondel statues. The south entrance has three sculptures with typical carvings that are in line with the buildings around it. The west entrance is a sculpture of three Indonesian maestros. At the side entrance, there is a gate with a Chinese style.

\subsubsection{Parking Facilities Area}

At the east, south, west entrance there is access to the car and motorcycle parking, while at the north entrance there is bus parking access with a bus stop located near the Ancol Art Market entrance. The quality and quantity of parking spaces are very good, but the motorcycle parking areas are not interconnected, so visitors must go in and out of the parking area to look for motor vehicles.

\subsubsection{Main Plaza Area}

The physical condition of Ancol Art Market Plaza is good with a ladder in the middle of the plaza that forms an amphitheater with three steps centering towards the stage, but at the bottom of the amphitheater there is no drainage hole to drain surface water, so that during the rainy season a slippery plaza surface can endanger people past it

\subsubsection{Stall Area A Area}

Block A stall area is designated as a sculpture and food stall. The large of trees in the area makes the area seem gloomy and dark.

\subsubsection{Stall Area B Area}

Block B stall is intended as a stall of works of art, masks, crafts, painting, carving. Circulation in the area is very convenient because of the pergola building. Toilet facilities in this area are difficult to find because of the hidden location and the absence of signage.

\subsubsection{Stall Area C Area}

Block $\mathrm{C}$ stall area is intended for sale of paintings. Every circulation is shaded by a pergola. Some circulation junctions are blocked by trees that are right at the intersection and can disrupt the movement of people who pass through it and make the stall area seem dark and gloomy. 


\subsubsection{North Art Space (NAS) Area}

The NAS area consists of a management office building and a museum of paintings, sculptures and other works of art. It has two different building styles, a combination of a stilt house and a minimalist house. In this area there is also a mosque as a supporting facility for managers, artists and visitors to the art market.

\subsection{Discussion}

Table 3. Evaluation the Aesthetic Aspects of the Hardscape Elements

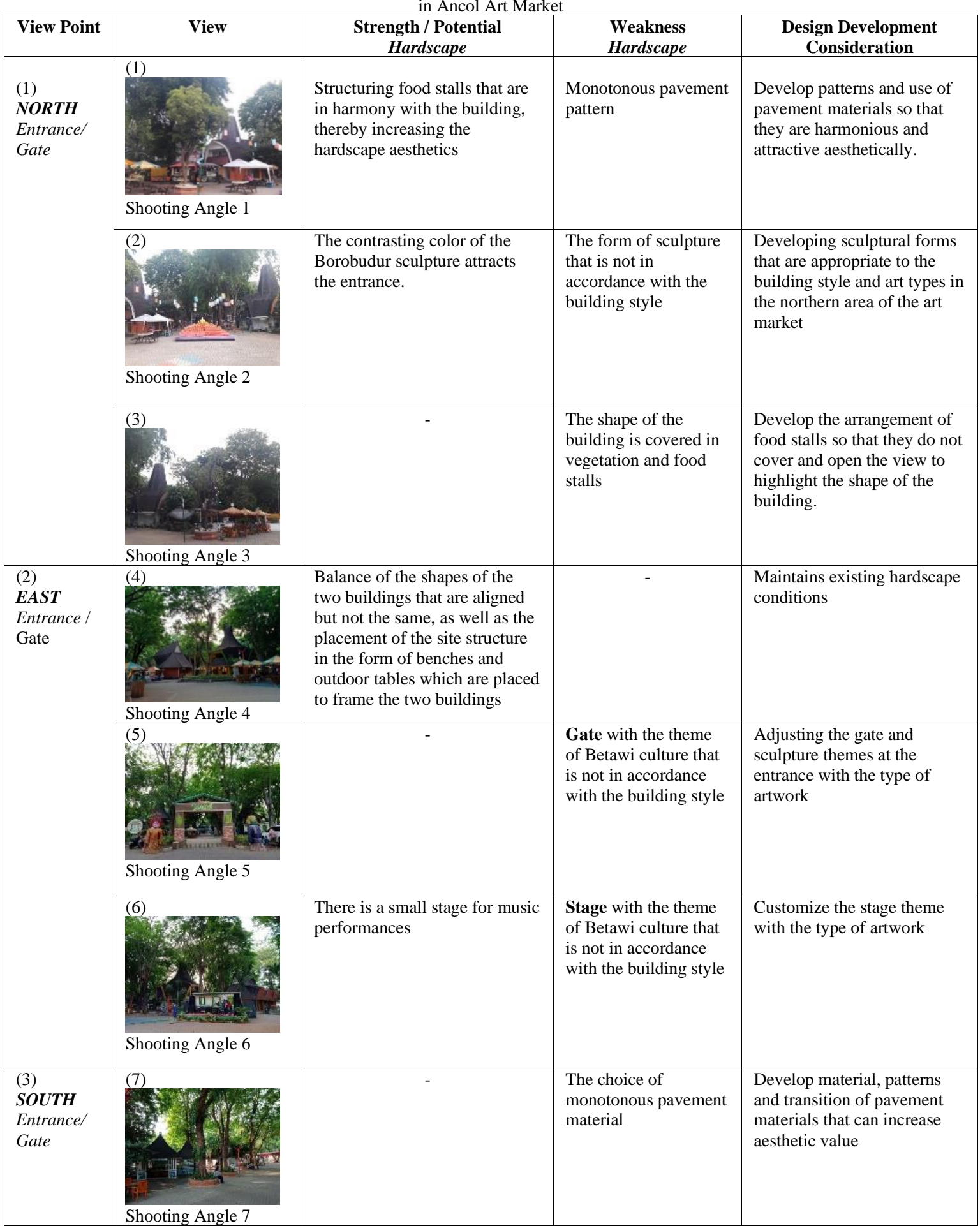




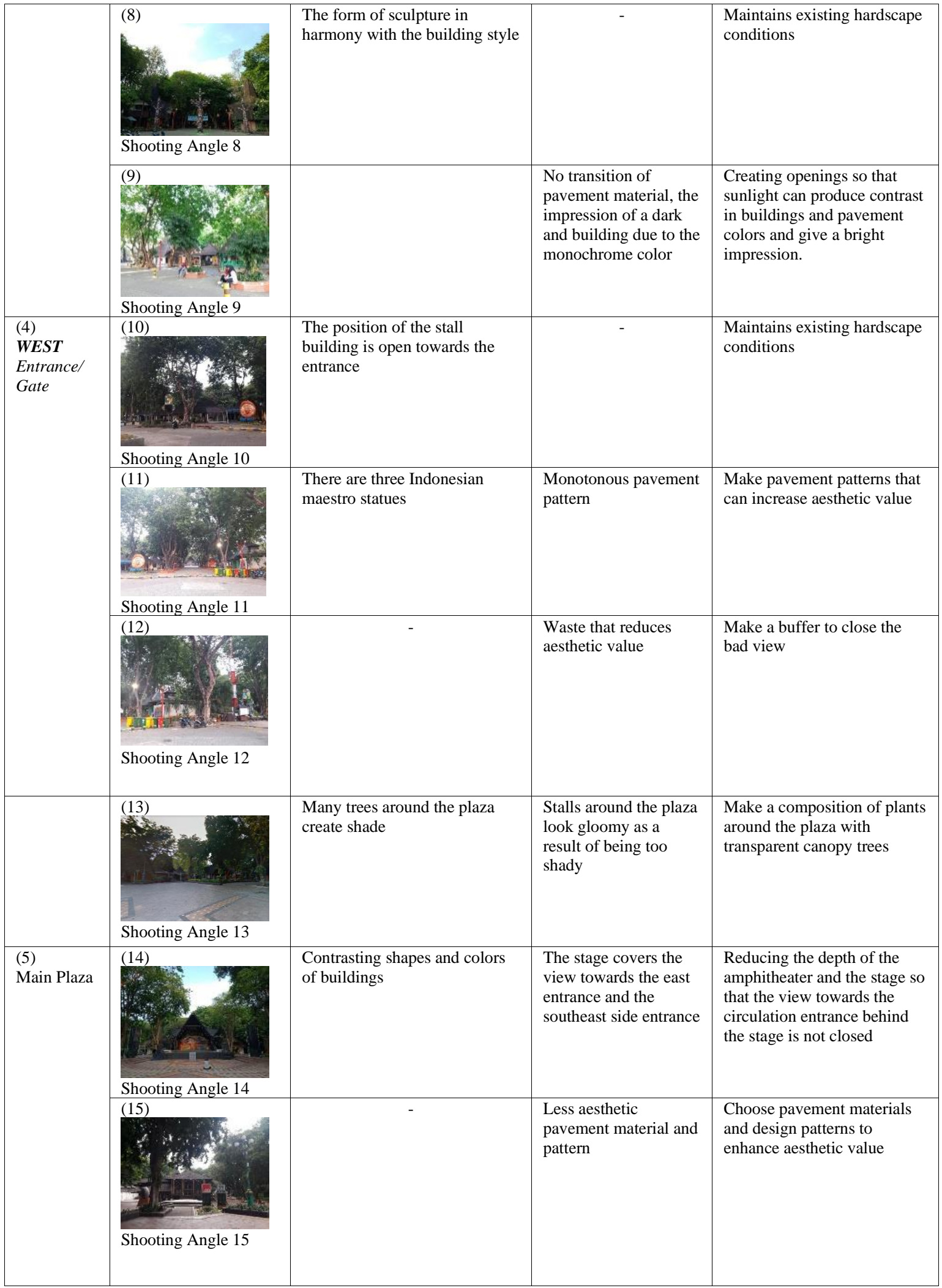

Source: Author

\subsection{Result}

a) Based on observations of the aesthetic assessment of Ancol Art Market, the highest quality is in the Entrance area. Structuring hardscape elements must be able to attract the interest of visitors to enter the area. The plaza area becomes an aesthetic attraction because it is located at the center of the Ancol Art Market and serves as a focal point for the function as a center for performing arts. The arrangement of Hardscape in the area of kiosks A, B, and C based on the functions and 
activities of the art exhibited needs to be developed with special building styles so that they have a distinctive and different character in each area.

b) Aesthetic assessment at five points of observation obtained results,

1. In the north entrance view, the highest aesthetic quality leads to the angle of shooting 1 . In shooting 2 and 3 it is necessary to improve the hardscape to improve the aesthetic quality and create harmony between the existing hardscape elements and the site environment.

2. In the east entrance view, the highest aesthetic quality leads to the angle of shooting four which leads to food stalls. The entrance area needs to be improved to adjust the hardscape theme / style to fit the art and building activities so as to improve the aesthetic quality.

3. At the south entrance view, the highest aesthetic quality leads to the angle of shooting 8 primary circulation areas with sculpture as the main site structure. Pavement elements need to be improved in shooting 7 and 9 so that changes in pavement and building materials are not bleak and dark.

4. At the west entrance view, the highest aesthetic quality leads to the angle of shooting 11 major circulation areas with Indonesian sculpture maestros. Shooting 12 on the back of a ceramic stall with a garbage collection reduces the aesthetic value, so it needs to be buffered to close the bad view and change the existing hardscape so that it is aligned with the entire element.

5. In the main plaza view, the highest aesthetic quality leads to the angle of shooting 14 stage areas. It is necessary to develop material shifts and pavement patterns to improve the aesthetics of the landscape pavement elements

c) Based on the results of observations made at the Ancol Art Market, there are a number of general issues, namely:

1. The gloomy impression in the art stall area is caused by the choice of pavement colors and materials that do not have a contrast value to the building elements, so it is necessary to develop changes in pavement material and color.

2. Parking area is not connected / integrated so it is necessary to make development plans by connecting each parking area to facilitate vehicle circulation.

3. The use of the same pavement material and the lack of directions make visitors often disoriented with the existing area, so it is necessary to plan the selection of different pavement materials in each area, using plant species with special characters and adding signage so that visitors can easily explore the Ancol Art Market area.

\section{CONCLUSIONS}

The Ancol Art Market Hardscape has the potential of sculpture in the South main entrance and the facial characters of three Indonesian masters in the West main entrance. This sculpture becomes an icon and creates a monumental and welcoming impression on the entrance. In the plaza area there is aesthetic potential in the form of a stage that functions as a venue for art and performance performances, but with a stage that leads to the north, the view on the East and Southeast entrance is covered by the back / back stage, so it is necessary to develop a design to optimize aesthetic potential which exists.

The building is dominated by art kiosks, but due to the very shady site conditions and the use of colors and textures from hardscape elements such as monochromatic buildings and pavement making the aesthetics of the view facing the art stalls seem bleak so visitors are reluctant to surround the area of the art stall and tend to visit main plaza.

Evaluation of aesthetic value at the Ancol Art Market is done by determining five points of observation that have a level of importance and visual potential aesthetic in the site, evaluating using the Formal Aesthetic method so that a point comparison is obtained from the aesthetic value available for the development of landscape design.

\section{REFERENCES}

[1] Alexander, Harold H. 1976. Design Criteria for Decision. Macmillan publishing, New York.

[2] Booth, Norman K. 1983. Basic Elements of Landscape Architectural Design. Waveland press, Ilinois.

[3] Daniel T.C., Vining J. (1983) Methodological Issues in the Assessment of Landscape Quality, Plenum Press, New York

[4] Panero, Julius dan Martin Zelnik. 1999. Human Dimension and Interior Space. Watson-Guptill Publications, New York.

[5] Sugiyono. 2014. Metode Penelitian Pendidikan Pendekatan Kuantitatif, Kualitatif Dan R\&D. Alfabeta, Bandung.

[6] Krisantia, Ina. 2012. Visual Landscape Evaluation of Tourism Area in West Java, Indonesia Based on Trisakti University Employees. Thesis Putra Malaysia University.

[7] Nugroho, Julius Andi. 2010. Fungsi Signage Ditinjau dari segi Estetik: Signage di Pasar Seni Ancol, Jakarta. Universitas Trisakti Jakarta. Online akses:

[8] http://www.library.trisakti.ac.id/opac/index.php/collection/detail/00000000000000026297/THE

[9] Cambridge university press. 2019. Meaning of Hardscape in English. Cambridge dictionary

[10] https://dictionary.cambridge.org/ (diakses pada 11 November 2019).

[11] PT Pembangunan Jaya Ancol. 2019. Pengertian Pasar Seni Ancol. Ancol Taman Impian. https://www.ancol.com

[12] (diakses pada 5 Oktober 2019).

[13] Pasar Seni Ancol Taman Impian, 2018, https://www.ancol.com/id/destination/pasar-seni

[14] (diakses 20 April 2020)

[15] Paparan Publik PT Pembangunan Jaya 2019,

[16] https://korporat.ancol.com/fm/app/public/files/Public\%20Expose\%20170619\%20fin.pdf

[17] (diakses 20 April 2019) 